The International Journal of Banking and Finance, Volume 9 (Number 4) 2012: pages 48-73

\title{
PORTFOLIO PREFERENCES ACROSS MARKETS: EVIDENCE FROM MUTUAL FUND OWNERSHIP
}

Wen-Hsiu Chou

Florida International University, United States of America

\begin{abstract}
This paper is about evaluating and comparing the portfolio preferences of domestic and foreign mutual funds in developed and emerging markets over the period 1998-2007. We find that foreign and domestic mutual funds have some different preferences toward firm characteristics and firms' information environments, and economic development affects the preferences for both types of funds. A country's characteristics and institutions also influence mutual fund investment decisions when fund managers form their portfolio holdings. Results further show that foreign and domestic mutual funds play a monitoring role in their portfolio firms, but foreign mutual funds cannot monitor firms effectively in emerging markets.
\end{abstract}

Key Words: Portfolio preference, Financial institutions, Mutual funds, International asset allocation, Developed vs merging markets

JEL Classification: G11, G15, G23

\section{Introduction to Literature on Ownership}

Capital markets have become even more integrated and globalized over the last two decades as revealed by the mutual dependence of markets during and after the global financial crisis. This globalization reduces investment costs and constraints, which allows investors to reallocate assets easily across markets. It also enables companies to finance their projects through world capital markets. This pool of foreign capital is especially important for emerging markets because foreign capital not only increases market value, it also improves liquidity while reducing cost of capital (Ferreira and Matos, 2008; Aggarwal et al., 2011). Despite the rapid liberalization of capital markets in both developed and emerging economies, foreign financing and access to 
foreign capital still vary considerably across firms and countries (Ferreira and Matos, 2008; Leuz and Warnock, 2009).

Previous studies in general focused on one developed market or some emerging markets as a group to reveal portfolio preferences of foreign investors; some studies focused on all national markets (for example, see Dahlquist and Robertsson, 2001; Aggarwal, Klapper and Wysocki, 2005; Ferreira and Matos, 2008). It is still not clear whether foreign investors have different preferences for firms in developed and firms in emerging markets. Fan, Wei, and Xu (2011) argue that firms in emerging markets are structurally different from firms in developed markets. Therefore, some factors discovered in the previous literature may have different effects on investor's choice of firms in developed versus emerging markets when attracting foreign investors. It is essential to understand what the differences are so firms in emerging markets may grow faster and more efficiently with the competition provided by foreign capital in order to catch up and compete with firms from developed markets.

This study focuses on one type of institutional investor namely mutual funds to investigate whether foreign investors have different preferences for firms in developed and emerging markets. It could document whether factors in previous studies show different effects on foreign and domestic ownership in developed and emerging markets. Mutual fund holdings are grouped into foreign and domestic portfolios. Mutual funds from locations domiciled in countries other than the country where the firm is located are classified as foreign investors. If mutual funds and firms are both located in the same country, the mutual fund ownership is classified as domestic ownership.

Second, we explore how firms' information environments affect mutual fund holding decisions. Previous studies usually document that foreign investors suffer from more information disadvantages than domestic investors (Bohn and Tesar, 1996). Thus, foreign investors in Japan and Sweden like to hold large stocks because large stocks are more visible and have more information than small stocks (Kang and Stulz, 1997; Dahlquist and Robertsson, 2001). We investigate whether foreign and domestic mutual fund ownership varies across different firmlevel information measures. Three dimensions of measure for a firm's information environment are used to proxy for the level of information asymmetry in different aspects. They are accounting standards (GAAP and IAS adoption), earnings management (accruals, earnings 
smoothing, and earnings correlation) and analyst variables (number of analysts covering a firm, analyst forecast errors, and analyst forecast dispersion). Results generally confirm the conjectures but with some variations.

Accounting standards and analysts play a major role on both foreign and domestic mutual fund ownership. Foreign ownership increases with good accounting standards, better analyst coverage, and lower analyst forecast dispersion. However, the effects of good accounting standards and lower analyst forecast dispersion reduce when foreign mutual funds invest in emerging markets but remain strong for domestic mutual funds in both developed and emerging markets. Earnings management seems to have little effect on the investment decisions for both foreign and domestic mutual fund holdings.

We also explore country characteristics as to whether these have an asymmetric impact on foreign and domestic mutual fund ownership. Foreign fund preference toward country characteristics is similar in both emerging and developed countries. Higher GDP and larger size of stock market have a negative effect on foreign ownership. These results are consistent with previous literature that international investors prefer small markets to diversify their portfolio holdings (Ferreira and Matos, 2008). Foreign trades, however, have a large positive impact on foreign mutual funds. This effect is indicative of the importance of visibility and familiarity for a country to attract foreign capital (Chan, Covrig and Ng, 2005). Contrary to foreign investors, a larger stock market has a positive effect but greater foreign trades have a negative impact on domestic mutual fund ownership. This negative effect of international trades is driven by emerging markets. In the developed markets, domestic fund ownership is positively associated with foreign trades.

Finally, legal environment plays important role on foreign mutual fund investment decisions. Foreign mutual funds can only effectively monitor their holding firms in developed markets. Previous literature documents that country’s laws and disclosure quality affect foreign investors' intention to enter a market or to hold a firm's stock (Gelos and Wei, 2005; Ferreira and Matos, 2008; Leuz et al., 2009). Here, security regulations, disclosure requirements, accounting standard, and anti-self-dealing are used to proxy for the enforcement of security laws, a country's disclosure quality, the firms' financial disclosure quality, and the quality of corporate governance in the country, respectively. 
These factors are supposed to be positively related to foreign mutual fund ownership. Results show that security regulations, disclosure requirements, accounting standard, and antiself-dealing are all positively related to foreign ownership in both developed and emerging markets. However, domestic mutual funds in general care more about disclosure requirements and anti-self-dealing but pay less attention to security regulations. When domestic mutual funds invest in emerging markets, all of these laws become important.

With regard to firm characteristics, existing results show that foreign mutual funds in general prefer firms with large size, lower dividend yields, higher operating performance, more cash holding, and lower closely-held ownership. They also prefer younger firms, growth stocks, member firms of MSCI index, and firms with American Depositary Receipt (ADR) issuance. These preferences are driven by developed markets because a relatively large number of listed companies worldwide are from developed markets. Contrary to developed markets, foreign mutual funds in emerging markets focus more on firms’ operating performance, such as ROE and sales growth. They also do not care about dividend yields. Although foreign mutual funds still prefer MSCI members, they have less of a preference for firms with ADR issuance. Aggarwal et al. (2005) explain that this may be due to low cross-listing in emerging markets. When pooling developed and emerging markets together, domestic mutual funds generally have preferences similar to foreign mutual funds, but they do not care about firm size and dividend yields. In addition, MSCI membership and ADR issuance actually are not important to domestic mutual fund ownership. The portfolio preferences are similar in developed markets. When comparing portfolio preferences in developed and emerging markets for domestic mutual funds, domestic mutual funds in emerging markets place more of an emphasis on dividend yields, ROE, and sales growth. Thus, the investment strategy that domestic investors adopt in emerging markets is generally firm-performance oriented.

This study therefore aims to make several contributions to the debate on ownership preferences across the world. The empirical results that link firm characteristics, information environments, and country institutions to both foreign and domestic investors expand the limited evidence on international portfolio allocation. In the literature, this study is most closely related to Dahlquist and Robertsson (2001), Aggarwal et al. (2005), and Ferreira and Matos (2008), which are examples of similar line of inquiries but with single aims. Dahlquist and Robertsson 
use firms in Sweden from 1991 to 1997 to investigate foreign and domestic investors’ portfolio preferences. Aggarwal et al. use U.S. mutual funds and focus on emerging markets with one year of data. Ferreira and Matos use overall institutional investors from 2000 to 2005 to test domestic and foreign investors’ portfolio preferences across all countries.

This study takes a first look at foreign and domestic mutual funds' holdings across 28 countries from 1998 to 2007 by comparing portfolio preferences of foreign and domestic mutual funds in both developed and emerging markets. In addition, data contain mutual funds from 62 countries, not just from the U.S. ${ }^{1}$ Second, this study adds to a growing body of papers that examine international portfolio allocation. Foreign investors have different portfolio preferences from domestic investors. In addition, both foreign and domestic mutual funds have different preferences toward firms in developed and emerging markets. Results also provide some additional information for researchers to solve the puzzle of home or foreign bias. The country's institutions play important role on mutual fund holding decisions. Finally, this study is one of the few studies that investigate the effective monitoring role of institutional investors in the international markets. Only domestic mutual funds play an effective monitoring role on firms in both developed and emerging markets. The reason may be that foreign investors face more information disadvantages in emerging markets than in developed markets.

The rest of the paper is organized as follows. Section 2 describes the sample and variables employed in the empirical tests, along with summary statistics. Section 3 presents the firm-level empirical results while in section 4 we evaluate the impact of country-level institutions on foreign and domestic mutual fund portfolio decisions. The final section concludes the paper.

\section{Data and Sample Description}

In this section, we briefly describe the construction of sample and report summary statistics of key variables. The main sample comprises the following data sources: worldwide mutual fund holdings from Thomson Reuters; stock returns and financial variables from Datastream and

\footnotetext{
${ }^{1}$ U.S.-based foreign institutions hold more than US\$ 2 trillion, non-U.S. foreign institutions hold US\$ 1.7 trillion, and domestic institutions hold US\$ 1.5 trillion in non-U.S. stocks. Ferreira and Matos document that U.S.-based foreign institutions, non-U.S. foreign institutions, and domestic institutions hold roughly the same level of assets in non-U.S. stocks.
} 
Worldscope; accounting standards from COMPUSTAT Global; and analyst information from $\mathrm{I} / \mathrm{B} / \mathrm{E} / \mathrm{S}$.

The Thomson Reuters database contains mutual fund equity holdings information at the firm level for over 32,031 mutual funds worldwide. The portfolio holdings data include the identifications of funds and securities, and the number of shares held in a firm by each fund. ${ }^{2}$ We require sample firms to have an assigned SEDOL code from COMPUSTAT Global from 1998 to 2007. There are 92,747 firm-year observations. However, the sample sizes in the multivariate analyses vary and are lower due to missing values for some variables. To classify fund holdings into domestic and foreign holdings, we check whether the funds and the holding firms are from the same countries. If both fund and firm are from the same country, the fund holdings are classified as domestic ownership; otherwise, foreign ownership applies.

We further split national markets into developed and emerging markets. There are 28 countries, 28,602 foreign mutual funds, 23,373 domestic mutual funds, and hence 92,747 firmyears in our sample over 1998 to 2007. The large number of worldwide mutual funds offers a common platform to analyze the investment decisions of a homogenous group of institutional investors who share the same investment savvy. Their investment decisions should offer the subtle yet important attitude that mutual funds have towards firms in developed and emerging markets. We first investigate the overall portfolio preference of domestic and foreign mutual funds, followed by the portfolio preference of domestic and foreign mutual funds for each of developed and emerging markets. Portfolio preferences include firm characteristics, firms' information environments, and country-level institutions. We also test whether foreign and domestic investors play an effective monitoring role on firms. Analyses provide several new and interesting results.

Drawing from the existing literature, firm characteristics in our regressions include: firm size (Size), book-to-market ratio $(B M)$, stock return $\left(\operatorname{Ret}_{12}\right)$, stock return volatility $\left(\sigma_{\text {Ret }}\right)$, dividend yield $(D Y)$, return on equity ( $R O E)$, a dummy variable (MSCI) that takes the value of one if the firm is included in the MSCI index for a given year, debt to asset ratio (DA), cash holdings $(\mathrm{CASH})$, closely-held ownership (CHold), sales growth (gSales), a dummy indicator $(A D R)$ that

\footnotetext{
${ }^{2}$ See Chan, Covrig, and Ng (2005) for a detailed description of the Thomson Reuters' mutual fund holdings database.
} 
equals one if a firm has issued American Depositary Receipts, and firm age (Age). Size is the log of market capitalization at year-end. $B M$ is the log of book-to-market equity ratio in June of year t. $\operatorname{Ret}_{12}$ is the average of monthly stock returns over year $\mathrm{t}-1 . \sigma_{\text {Ret }}$ is the standard deviation of monthly stock returns over year t-1. $D A$ is the ratio of long-term debt to total assets. $C A S H$ is the ratio of cash and short-term investments to total assets. CHold is the fraction of shares closely held by insiders and controlling shareholders in year t. gSales is the average of sales growth for years $\mathrm{t}-2$ and $\mathrm{t}-1$.

To assess the effect of firm-level information environment on foreign mutual fund ownership, firms' information measures include accounting standards (AccStd), analyst coverage (Nanalysts), forecast dispersion (Disp), forecast errors (Ferror), accruals (Accrual), earnings smoothing (Smooth), and earnings correlation (Corr). These variables evaluate three dimensions of information disclosure quality at the firm level. AccStd evaluates accounting standards; Nanlysts, Disp, and Ferror are related to the information disclosed by analysts. Accrual, Smooth, and Corr measure the earnings management. AccStd is a dummy variable set to one if the firm uses GAAP or IAS as its accounting standard. Nanalysts is the number of financial analysts covering a firm in year t. Disp is the standard deviation of analyst forecasts scaled by the mean of analyst forecasts in year t. Ferror is the absolute value of the difference between announced earnings and the mean of estimated earnings scaled by the mean of analyst forecasts in year $t$. Accrual is the magnitude of accruals. We follow Lai, Ng and Zhang (2012) to calculate the variable of Accrual. Smooth is the smoothness of the accounting reports and is the ratio of the standard deviation of operating income to the standard deviation of cash flows over the last five years. Corr is the correlation coefficient between change of accruals and change of cash flows over the last five years. When calculating Smooth and Corr, a minimum of three years is required.

Country characteristics included in the analyses are GDP per capita (GDP), stock market capitalization to GDP (MCAP), GDP growth (gGDP), trade to GDP ratio (TGDP), GDP growth volatility $(\sigma \mathrm{GDP})$, and stock market volatility $(\sigma \mathrm{MKT})$. All variables except stock market volatility are taken from the World Development Indicators. To access country-level information on disclosure or institutions, we implement indexes from La Porta et al. $(1998,2006)$. These indicators include security regulations, the accounting standard index, and the anti-self-dealing index. The index for disclosure requirements is from World Economic Forum. Median of the 
index scores across all countries is used to classify countries. Countries with score above the median are considered strongly regulated countries; otherwise they are considered weakly regulated countries.

Table 1: Country-level sample distribution and descriptive statistics

This table reports the time-series averages of country characteristics for 28 countries from 1998 to 2007, together with the number of firm-year observations (N(FYear)) covered in the sample and the fraction of shares held by foreign mutual funds (MF) in \%. Country characteristics include GDP per capita (GDP), stock market capitalization to GDP (MCAP), GDP growth (gGDP) in year t-1, trade to GDP ratio (TGDP) in year t, GDP growth volatility ( $\sigma \mathrm{GDP}$ ) over the last five years, and daily stock market volatility ( $\sigma \mathrm{MKT})$ over year $\mathrm{t}-1$.

\begin{tabular}{|c|c|c|c|c|c|c|c|c|}
\hline Country & N(FYear) & $\mathrm{MF}$ & GDP & MCAP & gGDP & TGDP & $\sigma$ GDP & $\sigma \mathrm{MKT}$ \\
\hline Argentina & 475 & 0.92 & 8.94 & 0.47 & 0.02 & 0.33 & 0.06 & 0.29 \\
\hline Australia & 5,165 & 2.60 & 10.01 & 1.12 & 0.03 & 0.41 & 0.01 & 0.17 \\
\hline Austria & 741 & 5.05 & 10.11 & 0.30 & 0.02 & 0.97 & 0.01 & 0.15 \\
\hline Belgium & 1,443 & 2.24 & 10.05 & 0.77 & 0.02 & 1.63 & 0.01 & 0.17 \\
\hline Brazil & 2,230 & 2.17 & 8.24 & 0.42 & 0.03 & 0.24 & 0.02 & 0.31 \\
\hline Denmark & 1,209 & 2.66 & 10.33 & 0.64 & 0.02 & 0.89 & 0.01 & 0.17 \\
\hline Finland & 1,185 & 6.20 & 10.12 & 1.46 & 0.04 & 0.74 & 0.01 & 0.31 \\
\hline France & 5,287 & 3.33 & 10.04 & 0.90 & 0.02 & 0.53 & 0.01 & 0.19 \\
\hline Germany & 5,422 & 3.96 & 10.06 & 0.52 & 0.02 & 0.71 & 0.01 & 0.19 \\
\hline Greece & 1,688 & 1.46 & 9.61 & 0.62 & 0.04 & 0.47 & 0.01 & 0.22 \\
\hline Hong Kong & 1,838 & 2.29 & 10.20 & 4.93 & 0.04 & 3.23 & 0.04 & 0.21 \\
\hline India & 3,660 & 2.51 & 6.27 & 0.56 & 0.07 & 0.37 & 0.02 & 0.26 \\
\hline Italy & 2,756 & 2.79 & 9.87 & 0.51 & 0.01 & 0.52 & 0.01 & 0.18 \\
\hline Japan & 20,984 & 1.67 & 10.54 & 0.84 & 0.01 & 0.24 & 0.01 & 0.21 \\
\hline Mexico & 1,039 & 2.47 & 8.69 & 0.26 & 0.03 & 0.61 & 0.03 & 0.23 \\
\hline Malaysia & 3,487 & 1.56 & 8.31 & 1.50 & 0.05 & 2.16 & 0.04 & 0.20 \\
\hline Netherlands & 1,801 & 5.79 & 10.10 & 1.22 & 0.02 & 1.29 & 0.01 & 0.18 \\
\hline Norway & 1,259 & 4.06 & 10.57 & 0.54 & 0.03 & 0.73 & 0.01 & 0.22 \\
\hline New Zealand & 691 & 3.07 & 9.58 & 0.41 & 0.03 & 0.61 & 0.02 & 0.16 \\
\hline Portugal & 487 & 2.24 & 9.30 & 0.47 & 0.02 & 0.67 & 0.01 & 0.16 \\
\hline South Africa & 1,625 & 2.01 & 8.08 & 1.98 & 0.04 & 0.56 & 0.01 & 0.25 \\
\hline Singapore & 2,427 & 2.13 & 10.08 & 2.04 & 0.06 & 4.28 & 0.04 & 0.19 \\
\hline Spain & 1,345 & 2.95 & 9.61 & 0.84 & 0.04 & 0.57 & 0.01 & 0.19 \\
\hline Sweden & 2,553 & 3.82 & 10.26 & 1.20 & 0.03 & 0.86 & 0.01 & 0.25 \\
\hline Switzerland & 2,459 & 4.61 & 10.45 & 2.66 & 0.02 & 0.84 & 0.01 & 0.16 \\
\hline Thailand & 3,548 & 1.86 & 7.73 & 0.56 & 0.04 & 1.30 & 0.05 & 0.29 \\
\hline Taiwan & 4,367 & 2.36 & 9.58 & 1.24 & 0.03 & 1.14 & 0.06 & 0.25 \\
\hline United Kingdom & 11,576 & 2.42 & 10.16 & 1.53 & 0.03 & 0.57 & 0.01 & 0.17 \\
\hline
\end{tabular}


Table 1 is a summary on 28 countries, their characteristics, and the number of firm-years covered in each country. The number of firm-year observations varies substantially across countries with 20,984 firm-years in Japan, 11,576 firm-years in the U.K., 5,422 firm-years in Germany, and only 475 firm-years in Argentina. Average foreign mutual fund holdings are generally higher for developed markets than for emerging markets, ranging from 0.92 per cent for Argentina to 6.20 per cent for Finland. Among the 28 countries in the sample, Norway, Hong Kong, India, Singapore, Taiwan, and Brazil have the greatest value of GDP, stock market size, GDP growth rate, trade to GDP ratio, GDP growth volatility, and market return volatility, respectively. However, India, Mexico, Italy, Japan, and Austria have the lowest value of GDP, stock market size, GDP growth rate, trade to GDP ratio, and stock market return volatility, respectively.

\section{Table 2: Firm-level sample istribution and descriptive statistics}

This table reports the time-series averages of firm characteristics from 1998 to 2007, together with the number of firm-year observations (N(FYear)) covered in the sample. Firm characteristics include the fraction of shares held by foreign mutual funds (MF) in \%, log of market capitalization (Size), log of book-to-market ratio (BM), average of past one-year monthly stock returns $\left(\operatorname{Ret}_{12}\right)$, standard deviation of past one year monthly stock returns $\left(\sigma_{\text {Ret }}\right)$, dividend yield (DY), return on equity ratio (ROE), MSCI membership (MSCI), debt to asset ratio (DA), cash holdings (CASH), closely-held ownership (CHold), sales growth (gSales), ADR issuance (ADR), and firm age (AGE).

\begin{tabular}{lrrrr}
\hline \hline & Mean & N(FYear) & Median & Std. dev. \\
\hline MF & 2.57 & 90,006 & 0.55 & 5.52 \\
SIZE & 5.64 & 73,529 & 5.51 & 1.90 \\
BM & -0.48 & 70,311 & -0.41 & 0.88 \\
Ret $_{12}$ & 0.01 & 73,503 & 0.01 & 0.05 \\
$\sigma_{\text {Ret }}$ & 0.13 & 73,463 & 0.11 & 0.09 \\
DY & 0.02 & 69,622 & 0.02 & 0.03 \\
ROE & 0.06 & 67,848 & 0.08 & 0.25 \\
MSCI & 0.46 & 73,907 & 0.00 & 0.50 \\
DA & 0.23 & 69,392 & 0.17 & 0.23 \\
CASH & 0.15 & 65,889 & 0.10 & 0.16 \\
CHold & 0.43 & 63,301 & 0.42 & 0.23 \\
gSales & 1.15 & 68,406 & 1.07 & 0.47 \\
ADR & 0.04 & 73,907 & 0.00 & 0.19 \\
AGE & 13.28 & 73,630 & 11.00 & 9.80 \\
\hline \hline
\end{tabular}


Table 2 reports the distribution of variables at the firm level across all countries employed in the analyses. Foreign mutual funds hold an average of 2.57 per cent of shares for the 90,006 total firm-year observations. Around 4 per cent of the firms have issued ADR, and around 46 per cent of the firms are members of MSCI index. Closely-held ownership applies to an average of 43 per cent of the shares. Firms in the sample generally have a negative BM and a positive past return. They also pay dividends and have a sales growth rate of 15 per cent. In an unreported table, the correlations between variables in the sample are moderately low, suggesting that the problem of multicollinearity should be minor.

\section{Determinants of Mutual Fund Holdings at the Firm Level}

Previous literature shows that U.S.-based foreign investors usually prefer firms with better information disclosure or firms that are more visible to foreigners such as large firms, firms with ADR issuance, and MSCI member countries. One explanation is that foreign investors suffer from an information disadvantage. Therefore, foreign and domestic investors should have some different portfolio preferences if foreign and domestic investors possess different levels of private information about local firms. In this section, we report findings on firm-level determinants of portfolio preferences across all countries for foreign and domestic mutual funds. Following this are the firm characteristics for each developed and emerging market for both foreign and domestic mutual funds. Determinants include firm characteristics and information environment.

\subsection{What Attracts Foreign and Domestic Mutual Funds?}

We first present results on which firm characteristics mutual fund investors care about the most. In this test, we control for country fixed effects and year fixed effects, and all associated $t$ statistics are calculated based on standard errors adjusted for heteroskedasticity and firm-level clustering. Therefore, firm characteristics across countries in the regressions should be comparable.

Table 3 is a summary of results. In the first column of left panel, the foreign mutual fund 


\section{Table 3: Tobit regression results of foreign and domestic mutual fund ownership on firm characteristics}

This table reports the regression results of mutual fund ownership on various firm characteristics with t-statistics of the coefficient estimates in parentheses. In the three models on the left side, the dependent variable is foreign mutual fund ownership. Results are first reported by including all countries, followed by developed countries, and lastly emerging countries. In the three models on the right, the dependent variable is domestic mutual fund ownership. Firm characteristics include variables described in Table 2. The sample period is from 1998 to 2007. Year and country dummies are added to control for year and country effects, and clustered standard errors are corrected at the firm level. N(FYear) is the number of firm-year observations.

\begin{tabular}{|c|c|c|c|c|c|c|}
\hline \multirow[b]{2}{*}{ VARIABLES } & \multicolumn{3}{|c|}{ Foreign Mutual Funds } & \multicolumn{3}{|c|}{ Domestic Mutual Funds } \\
\hline & All & Developed & Emerging & All & Developed & Emerging \\
\hline \multirow[t]{2}{*}{ SIZE } & 0.83 & 0.82 & 0.96 & -0.03 & -0.03 & -0.11 \\
\hline & $(25.48)$ & (23.19) & $(9.94)$ & $(-1.09)$ & $(-0.73)$ & $(-1.45)$ \\
\hline \multirow[t]{2}{*}{$\mathrm{BM}$} & -0.30 & -0.21 & -0.56 & -0.62 & -0.58 & -0.80 \\
\hline & $(-5.70)$ & $(-3.45)$ & $(-4.98)$ & $(-9.80)$ & $(-8.32)$ & $(-5.20)$ \\
\hline \multirow[t]{2}{*}{$\operatorname{Ret}_{12}$} & -5.41 & -5.37 & -4.95 & -2.19 & -4.89 & 6.85 \\
\hline & $(-8.14)$ & $(-6.86)$ & $(-3.75)$ & $(-3.01)$ & $(-5.66)$ & (5.13) \\
\hline \multirow[t]{2}{*}{$\sigma_{\text {Ret }}$} & 2.39 & 3.02 & 0.22 & 2.29 & 2.27 & -0.40 \\
\hline & $(4.88)$ & $(5.28)$ & $(0.24)$ & (3.82) & $(3.01)$ & $(-0.45)$ \\
\hline \multirow[t]{2}{*}{ DY } & -2.82 & -3.65 & -1.94 & 0.96 & -1.32 & 5.06 \\
\hline & $(-2.97)$ & $(-3.28)$ & $(-1.00)$ & $(0.78)$ & $(-0.92)$ & $(2.20)$ \\
\hline \multirow[t]{2}{*}{ ROE } & 0.54 & 0.39 & 1.33 & 1.52 & 1.43 & 2.06 \\
\hline & (3.64) & $(2.41)$ & (3.73) & $(9.00)$ & (7.50) & (6.37) \\
\hline \multirow[t]{2}{*}{ MSCI } & 0.55 & 0.54 & 0.55 & -0.47 & -0.35 & -0.76 \\
\hline & (5.98) & $(5.24)$ & $(2.54)$ & $(-4.40)$ & $(-2.80)$ & $(-3.64)$ \\
\hline \multirow[t]{2}{*}{ DA } & 0.07 & 0.07 & 0.34 & 0.23 & 0.17 & 0.60 \\
\hline & $(0.39)$ & $(0.34)$ & $(0.71)$ & (1.06) & $(0.65)$ & (1.61) \\
\hline \multirow[t]{2}{*}{$\mathrm{CASH}$} & 1.38 & 1.23 & 1.60 & -0.60 & -0.74 & -0.08 \\
\hline & $(5.01)$ & $(4.02)$ & $(2.44)$ & $(-2.19)$ & $(-2.41)$ & $(-0.13)$ \\
\hline \multirow[t]{2}{*}{ CHold } & -3.70 & -3.79 & -3.67 & -3.47 & -3.31 & -3.95 \\
\hline & $(-18.21)$ & $(-16.19)$ & $(-8.49)$ & $(-18.05)$ & $(-14.89)$ & $(-10.50)$ \\
\hline \multirow[t]{2}{*}{ gSales x100 } & -0.01 & -0.02 & 0.17 & 0.02 & 0.01 & 0.12 \\
\hline & $(-1.00)$ & $(-1.09)$ & $(4.90)$ & $(0.60)$ & $(0.53)$ & (2.61) \\
\hline \multirow[t]{2}{*}{ ADR } & 0.56 & 0.50 & 0.76 & -1.36 & -1.25 & -1.68 \\
\hline & (1.99) & (1.78) & $(0.92)$ & $(-7.01)$ & $(-5.62)$ & $(-4.47)$ \\
\hline \multirow[t]{2}{*}{ AGE } & -0.05 & -0.04 & -0.06 & -0.04 & -0.04 & -0.08 \\
\hline & $(-9.93)$ & $(-9.27)$ & $(-3.29)$ & $(-7.45)$ & $(-6.62)$ & $(-4.84)$ \\
\hline N(FYear) & 52,830 & 42,876 & 9,954 & 50,858 & 40,320 & 10,538 \\
\hline Pseudo $\mathrm{R}^{2}$ & $4.21 \%$ & $4.55 \%$ & $3.60 \%$ & $3.64 \%$ & $3.83 \%$ & $2.92 \%$ \\
\hline
\end{tabular}


holdings are mainly positive and statistically significantly related to firm size, ROE, MSCI membership, cash holdings, and ADR issuance.

Results indicate that firms with more information disclosure and better visibility attract more foreign investors, for example, large firms, firms with MSCI membership, and firms with ADR issuance. The results further demonstrate that foreign ownership is negatively associated with book-to-market ratio, dividend yields, closely-held shares, and firm age. Thus, foreign investors prefer growth stocks, low dividend payouts, less closely-held shares, and younger firms. Consistent with Ferreira and Matos (2008), domestic mutual funds (the first column of right panel) generally show a lower preference toward large firms, firms with ADR issuance, or firms listed in the MSCI index. They also prefer firms with lower cash holdings. Since domestic investors have more information about local firms, they rely less on firm size to make their

investment decisions. Similar to foreign investors, domestic mutual funds show preference toward growth stocks, better ROE, less closely-held shares, and younger firms.

When countries are separated into developed and emerging markets, foreign investors' portfolio preferences in developed markets are generally consistent with their overall portfolio preferences across all countries. Contrary to the portfolio preferences for foreign investors in developed markets, foreign investors in emerging markets focus more on operating performance, such as strong ROE and sales growth. Dividend yield also plays no role in foreign mutual fund ownership. Similar to foreign mutual funds, domestic mutual funds have some significantly different portfolio preferences for firms in developed and emerging markets. For example, domestic mutual funds in the emerging markets do not care about cash holdings but prefer firms that pay more dividends. It is interesting to note that ADR issuance has almost no effect on foreign fund holdings in the emerging markets. There are two possible explanations: (i) the number of ADR listings may be low in the emerging markets (Aggarwal et al., 2005), and (ii) the data include all mutual funds worldwide, and ADRs have less effect on foreign mutual funds from countries other than the U.S.

\subsection{Information Disclosure Quality and Mutual Fund Holding Preference}

Next set of results are on disclosure affects in both foreign and domestic mutual fund holdings in developed and emerging markets. In this test, three dimensions of information 
disclosure are used - accounting standards, analyst variables, and earnings management - to measure a firm’s information environment.

To conduct the test, a dummy is set to one if the firm uses IAS or GAAP as its accounting standard. In the accounting literature, both accounting standards and auditor quality matter most for the quality of financial reports and foreign investors (see Bradshaw, Bushee, and Miller, 2004; Francis, 2004; Covrig, DeFond, and Hung, 2007). However, as Francis and Wang (2008) document, COMPUSTAT Global does not give proper auditor identification for Japan, South Korea, India, and Pakistan. In addition, there is no precise way to determine the auditors' identification in these four countries. Therefore, this study focuses on accounting standards to measure the reliability, consistency and comparability of accounting information for a firm. To measure the information delivered by financial analysts for a firm, we implement the number of analysts covering the firm, analyst forecast dispersion, and analyst forecast errors. The magnitude of accruals, earnings smoothing, and the correlation between change in accruals and change in operating cash flows are the measures for earnings management. To test the relation between information disclosure and mutual fund holdings, and to see what measures have the most significant effects, each category of information measures (accounting standards, financial analysts, and earnings management) is included one by one in order to avoid the problems of reduced observations and collinearity between any two categories of measures.

Table 4 reports the results. It is obvious that accounting standards and information provided by analysts both play a major role on mutual funds investment decisions. When a firm adopts better accounting standards, foreign and domestic mutual funds will increase their holdings in the firm by 0.76 per cent and 0.54 per cent, respectively. This is economically significant. From Table 2, the average foreign mutual fund holding is 2.57 per cent. Thus, an increase of 0.76 per cent for foreign shares is representative of 30 per cent increase in ownership. The effect of better accounting standards on foreign mutual fund ownership is stronger in developed markets but reduces in emerging markets. This indicates that emerging markets lack enforcement, which weakens the link between better accounting standards and foreign holdings (Francis and Wang, 2008). However, better accounting standards have a more significant impact on domestic mutual fund investment decisions in emerging markets than in developed markets. This may imply that domestic investors have an information advantage over foreign investors. 


\section{Table 4: Information disclosure quality and mutual fund holding preference}

This table reports the regression results of mutual fund ownership on various measures for firmlevel information disclosure. Measures of a firm's information environment are categorized in the following three ways. (i) Accounting standards: A dummy for the firm's accounting standards (AccStd) that equals one if the firm uses IAS or GAAP as its accounting standard; (ii) Analyst variables, the number of analysts covering the firm (Nanalysts), analyst forecast dispersion (Disp), and analyst forecast errors (Ferror); (iii) Degree of earnings management: The magnitude of accruals (Accrual), earnings smoothing (Smooth), and correlation between the change in accruals and change in operating cash flows (Corr). Control variables include variables used in Table 3. t-statistics reported in parentheses are calculated based on clustered firm-level heteroskedasticity-adjusted standard errors. N(FYear) is the number of firm-year observations. The sample period is from 1998 to 2007 . Year and country dummies are added to control for year and country effects.

\begin{tabular}{|c|c|c|c|c|c|c|c|c|c|}
\hline \multirow[b]{2}{*}{ VARIABLES } & \multicolumn{3}{|c|}{ All Countries } & \multicolumn{3}{|c|}{ Developed Market } & \multicolumn{3}{|c|}{ Emerging Market } \\
\hline & $(1)$ & $(2)$ & $(3)$ & $(4)$ & $(5)$ & $(6)$ & $(7)$ & $(8)$ & $(9)$ \\
\hline & \multicolumn{9}{|c|}{ Panel A: Foreign Mutual Funds } \\
\hline \multirow[t]{2}{*}{ Nanalysts } & & 0.09 & & & 0.08 & & & 0.19 & \\
\hline & & $(7.36)$ & & & $(5.82)$ & & & $(5.16)$ & \\
\hline \multirow[t]{2}{*}{ Disp } & & -0.41 & & & -0.38 & & & -0.60 & \\
\hline & & $(-2.50)$ & & & $(-2.18)$ & & & $(-1.25)$ & \\
\hline \multirow[t]{2}{*}{ Ferror } & & -0.01 & & & -0.01 & & & -0.04 & \\
\hline & & $(-0.25)$ & & & $(-0.14)$ & & & $(-0.47)$ & \\
\hline \multirow[t]{2}{*}{ AccStd } & 0.76 & & & 0.82 & & & 0.78 & & \\
\hline & $(5.18)$ & & & $(5.30)$ & & & $(1.71)$ & & \\
\hline \multirow[t]{2}{*}{ Accrual } & & & -0.03 & & & -0.06 & & & 0.08 \\
\hline & & & $(-0.68)$ & & & $(-1.34)$ & & & $(0.75)$ \\
\hline \multirow[t]{2}{*}{ Smooth } & & & 0.02 & & & 0.06 & & & -0.22 \\
\hline & & & $(0.28)$ & & & $(0.62)$ & & & $(-1.42)$ \\
\hline \multirow[t]{2}{*}{ Corr } & & & -0.17 & & & -0.20 & & & -0.11 \\
\hline & & & $(-1.64)$ & & & $(-1.65)$ & & & $(-0.49)$ \\
\hline N(FYear) & 41,766 & 33,313 & 43,670 & 34,436 & 27,629 & 35,588 & 7,330 & 5,684 & 8,082 \\
\hline \multirow[t]{2}{*}{ Pseudo $\mathrm{R}^{2}$} & $4.40 \%$ & $4.63 \%$ & $4.43 \%$ & $4.67 \%$ & $4.81 \%$ & $4.71 \%$ & $4.08 \%$ & $4.28 \%$ & $3.99 \%$ \\
\hline & & l Countr & & Dev & loped M & arket & Em & rging $\mathrm{M}$ & Irket \\
\hline \multirow[t]{2}{*}{ VARIABLES } & $(1)$ & $(2)$ & $(3)$ & $(4)$ & $(5)$ & $(6)$ & $(7)$ & $(8)$ & (9) \\
\hline & \multicolumn{9}{|c|}{ Panel B: Domestic Mutual Funds } \\
\hline \multirow[t]{2}{*}{ Nanalysts } & & 0.05 & & & 0.04 & & & 0.09 & \\
\hline & & $(5.87)$ & & & $(4.50)$ & & & $(4.17)$ & \\
\hline \multirow[t]{2}{*}{ Disp } & & -0.87 & & & -0.79 & & & -0.94 & \\
\hline & & $(-5.30)$ & & & $(-4.37)$ & & & $(-2.49)$ & \\
\hline \multirow[t]{2}{*}{ Ferror } & & 0.00 & & & 0.00 & & & -0.05 & \\
\hline & & $(-0.06)$ & & & $(-0.07)$ & & & $(-0.54)$ & \\
\hline
\end{tabular}




\begin{tabular}{|c|c|c|c|c|c|c|c|c|c|}
\hline AccStd & $\begin{array}{c}0.54 \\
(3.75)\end{array}$ & & & $\begin{array}{c}0.41 \\
(2.58)\end{array}$ & & & $\begin{array}{c}1.07 \\
(3.20)\end{array}$ & & \\
\hline Accrual & & & $\begin{array}{c}-0.07 \\
(-1.58)\end{array}$ & & & $\begin{array}{c}-0.09 \\
(-1.63)\end{array}$ & & & $\begin{array}{c}0.00 \\
(0.04)\end{array}$ \\
\hline Smooth & & & $\begin{array}{c}0.09 \\
(1.11)\end{array}$ & & & $\begin{array}{c}0.04 \\
(0.43)\end{array}$ & & & $\begin{array}{c}0.25 \\
(1.50)\end{array}$ \\
\hline Corr & & & $\begin{array}{c}-0.02 \\
(-0.15)\end{array}$ & & & $\begin{array}{c}-0.06 \\
(-0.44)\end{array}$ & & & $\begin{array}{c}0.22 \\
(1.09)\end{array}$ \\
\hline $\mathrm{N}$ (FYear) & 40,108 & 32,136 & 41,252 & 32,199 & 26,684 & 33,199 & 7,909 & 5,452 & 8,053 \\
\hline Pseudo $\mathrm{R}^{2}$ & $3.91 \%$ & $4.16 \%$ & $3.85 \%$ & $4.16 \%$ & $4.39 \%$ & $4.06 \%$ & $2.85 \%$ & $3.37 \%$ & $2.73 \%$ \\
\hline
\end{tabular}

Therefore, the lack of enforcement does not affect domestic mutual funds.

Among analyst variables, the number of analysts and analyst forecast dispersion are positively and negatively associated with the investment decisions of both foreign and domestic mutual funds, respectively. These two variables are significant at conventional levels. However, the significance of analyst forecast dispersion in emerging markets reduces for foreign investors. Analysts' forecast errors have the least effect on investment decisions for domestic and foreign mutual funds. This may show that visibility is more important than information quality for mutual funds because higher analyst coverage indicates that the firm is more visible and provides more information to investors. It is also possible that investors have difficulty judging the accuracy of information so the correlation between fund ownership and forecast errors is not significant. Among all three earnings management measures, none of them has a significant effect on foreign or domestic holdings. These results are consistent between foreign and domestic mutual funds.

\section{Determinants of Mutual Fund Holdings at the Country Level}

This section is on how country characteristics affect foreign and domestic mutual fund ownership. Previous literature documents that a country's information disclosure quality and its institutions both affect foreign investors' intention to enter the stock market. For example, Leuz, Nanda, and Wysocki (2003) show that information quality is poor for firms in countries with weak investor protection. Gelos and Wei (2005) and Leuz et al. (2009) show that low country information 
transparency or information disclosure quality reduces foreign investment and is likely to exacerbate the degree of information asymmetry faced by foreign investors. Therefore, foreign mutual funds' ownership varies with the countries' institutions and information disclosure quality. However, it is not clear whether such country characteristics affect domestic mutual funds' investment decisions. This study first examines how a country's characteristics affect both foreign and domestic mutual fund ownership. Then, we test how mutual funds' ownership varies with a country's information disclosure. Lastly, we test whether foreign or domestic mutual funds play an effective role on monitoring.

\subsection{Country Characteristics and Mutual Fund Holdings}

Here, country characteristics included in the test are a dummy variable to indicate emerging market, GDP, stock market capitalization to GDP, GDP growth, ratio of trade (exports plus imports) to GDP, standard deviation of annual GDP growth over the past five years, and the annualized standard deviation of daily stock market returns over the past one year. The dependent variable is mutual fund ownership in percent at the firm level. Control variables include all firm-level characteristics used in Table 3. t-statistics are reported with clustered firmlevel heteroskedasticity-adjusted standard errors. Table 5 reports the results.

From the left panel of Table 5, it is clear that foreign mutual funds invest less in emerging markets. If all conditions are equal, foreign investors reduce their ownership by an average of $1.40 \%$ in emerging markets when compared with developed markets. All variables except trade to GDP and stock market volatility are negatively related to foreign ownership. Thus, foreign investors actually invest less in big countries and this is caused by the diversification needs for foreign investors (Ferreira and Matos, 2008). International trading seems to be an important factor for attracting foreign capital. If a country has a stronger connection with other countries, foreign investors tend to invest more in this country. The portfolio preference is similar for foreign investors in both developed and emerging markets except when considering GDP, GDP growth volatility, and stock market volatility. The coefficients of GDP, GDP growth volatility, and stock market volatility become insignificant in emerging markets for foreign investors.

For domestic mutual funds (right panel of Table 5), there is no difference in fund ownership between developed and emerging markets. Contrary to foreign investors, domestic mutual funds' 
ownership is positively related to market size and negatively related to trade to

\section{Table 5: Tobit regression results on mutual fund ownership on country characteristics}

This table reports regression results of foreign and domestic mutual fund ownership on various country characteristics. Country variables include EmeD that is equal to one if the country is an emerging country, GDP per capita (GDP), stock market capitalization to GDP (MCAP), GDP growth, ratio of exports plus imports to GDP (TGDP), standard deviation of annual GDP growth over past five years ( $\sigma \mathrm{GDP}$ ), and the annualized standard deviation of daily stock market returns over year t-1 $(\sigma \mathrm{MKT})$. Control variables include firm-level variables used in Table 3. t-statistics reported in parentheses are calculated based on clustered firm-level heteroskedasticity-adjusted standard errors. N(FYear) is the number of firm-year observations. The sample period is from 1998 to 2007. Year dummies are added to control for year effect.

\begin{tabular}{|c|c|c|c|c|c|c|}
\hline & \multicolumn{3}{|c|}{ Foreign Mutual Funds } & \multicolumn{3}{|c|}{ Domestic Mutual Funds } \\
\hline & All & Developed & Emerging & All & Developed & Emerging \\
\hline VARIABLES & (1) & $(2)$ & $(3)$ & (4) & $(5)$ & (6) \\
\hline EmeD & $\begin{array}{c}-1.40 \\
(-6.51)\end{array}$ & & & $\begin{array}{c}-0.38 \\
(-1.67)\end{array}$ & & \\
\hline GDP & $\begin{array}{c}-0.38 \\
(-4.44)\end{array}$ & $\begin{array}{c}-1.67 \\
(-7.02)\end{array}$ & $\begin{array}{c}-0.09 \\
(-0.92)\end{array}$ & $\begin{array}{c}-0.44 \\
(-5.14)\end{array}$ & $\begin{array}{c}-0.59 \\
(-2.41)\end{array}$ & $\begin{array}{c}-0.27 \\
(-2.76)\end{array}$ \\
\hline MCAP & $\begin{array}{c}-0.25 \\
(-3.53)\end{array}$ & $\begin{array}{c}-0.16 \\
(-2.09)\end{array}$ & $\begin{array}{c}-0.40 \\
(-1.91)\end{array}$ & $\begin{array}{c}0.81 \\
(11.78)\end{array}$ & $\begin{array}{c}0.55 \\
(8.36)\end{array}$ & $\begin{array}{c}1.56 \\
(5.89)\end{array}$ \\
\hline gGDP & $\begin{array}{c}-9.80 \\
(-5.48)\end{array}$ & $\begin{array}{l}-19.85 \\
(-6.36)\end{array}$ & $\begin{array}{c}-5.09 \\
(-2.40)\end{array}$ & $\begin{array}{c}2.99 \\
(1.62)\end{array}$ & $\begin{array}{l}15.54 \\
(4.66)\end{array}$ & $\begin{array}{c}-4.96 \\
(-1.86)\end{array}$ \\
\hline TGDP & $\begin{array}{c}0.76 \\
(9.85)\end{array}$ & $\begin{array}{c}0.91 \\
(8.28)\end{array}$ & $\begin{array}{c}0.59 \\
(3.29)\end{array}$ & $\begin{array}{c}-0.37 \\
(-5.63)\end{array}$ & $\begin{array}{c}0.73 \\
(7.25)\end{array}$ & $\begin{array}{c}-1.95 \\
(-13.58)\end{array}$ \\
\hline$\sigma \mathrm{GDP}$ & $\begin{array}{c}-9.79 \\
(-3.64)\end{array}$ & $\begin{array}{l}-31.37 \\
(-5.15)\end{array}$ & $\begin{array}{c}-3.51 \\
(-0.96)\end{array}$ & $\begin{array}{c}-51.10 \\
(-15.74)\end{array}$ & $\begin{array}{l}-175.56 \\
(-22.05)\end{array}$ & $\begin{array}{c}-8.91 \\
(-2.52)\end{array}$ \\
\hline$\sigma \mathrm{MKT}$ & $\begin{array}{c}1.83 \\
(2.50)\end{array}$ & $\begin{array}{c}5.83 \\
(4.73)\end{array}$ & $\begin{array}{c}-0.83 \\
(-0.96)\end{array}$ & $\begin{array}{c}1.01 \\
(1.48)\end{array}$ & $\begin{array}{c}1.65 \\
(1.35)\end{array}$ & $\begin{array}{c}0.52 \\
(0.52)\end{array}$ \\
\hline N(FYear) & 52,527 & 42,573 & 9,954 & 50,637 & 40,099 & 10,538 \\
\hline Pseudo $\mathrm{R}^{2}$ & $3.44 \%$ & $3.67 \%$ & $3.40 \%$ & $2.19 \%$ & $2.53 \%$ & $2.64 \%$ \\
\hline
\end{tabular}

GDP. It is reasonable that the size of equity market is positively related to domestic fund ownership because market size in general is associated with local people's wealth. Since foreign ownership is positively related to trade to GDP, the negative correlation between domestic ownership and trade to GDP indicates that well-known countries attract more foreign investors and this causes domestic investors to have a small fraction of ownership. The finding from emerging markets supports this argument because firms in emerging markets on average are 
smaller than firms in developed markets. An increased foreign ownership in emerging markets will lead to a significant drop in domestic ownership.

\subsection{Country Institutions and Mutual Fund Holdings}

This subsection provides results on how country-level institutions affect investors' decision making when they form their portfolio holdings. Previous literature documents that countries' laws and disclosure quality affect foreign investors' intention to enter a market or to hold a firm's stock (Gelos and Wei, 2005; Ferreira and Matos, 2008; Leuz et al., 2009). Here, we use security regulation to proxy for the enforcement of security laws, disclosure requirement to proxy for a country’s disclosure quality, accounting standard to proxy for the countries' financial disclosure quality, and anti-self-dealing to proxy for the quality of corporate governance in the country. These factors are supposed to be positively related to foreign mutual fund ownership. However, the effect of these factors on mutual fund ownership is still not clear when markets are further split into developed and emerging markets, and funds are grouped into foreign and domestic mutual funds.

Table 6 first reports the results by using foreign mutual funds as the sample in Panel A and then by using domestic mutual funds as the sample in Panel B. It is obvious that a country's institutions matter to foreign investors in both developed and emerging markets. However, the effect of institutions seems to be stronger in developed markets than in emerging markets except for security regulations. One possible explanation for this is that developed countries have better abilities to fairly enforce laws. Among all institutional variables, disclosure requirements have the greatest effect on foreign holdings, while security regulations, accounting standard and antiself-dealing are all important to foreign investors. Thus, to attract foreign capital, emerging countries have to improve their institutions to protect investors and provide quality information disclosure.

Contrary to foreign investors, domestic mutual funds have different behaviors in both developed and emerging markets. When all countries are pooled together, domestic mutual funds seem to not care about security regulations and accounting standard. However, disclosure requirements and anti-self-dealing are still important for domestic mutual funds. Since domestic mutual funds know local firms better, information asymmetry is less of a problem when they 


\section{Table 6: Country institutions and mutual fund holding preference}

This table reports regression results of mutual fund ownership on various measures for country-level information disclosure. The dependent variable is the foreign or domestic mutual fund ownership in all markets, developed markets, and emerging markets. The measures for information disclosure quality at the country level include dummies for security regulations, disclosure requirements, accounting standards index, and anti-self-dealing index. See La Porta et al. (2006) for the description of the indexes. The dummy for each country disclosure measure is equal to one if the country has an index score above the median of all countries. Control variables include country variables used in Table 5 and firm variables used in Table 3. t-statistics reported in parentheses are calculated based on clustered firm-level heteroskedasticity-adjusted standard errors. N(FYear) is the number of firm-year observations. The sample period is from 1998 to 2007. Year and country dummies are added to control for year and country effects.

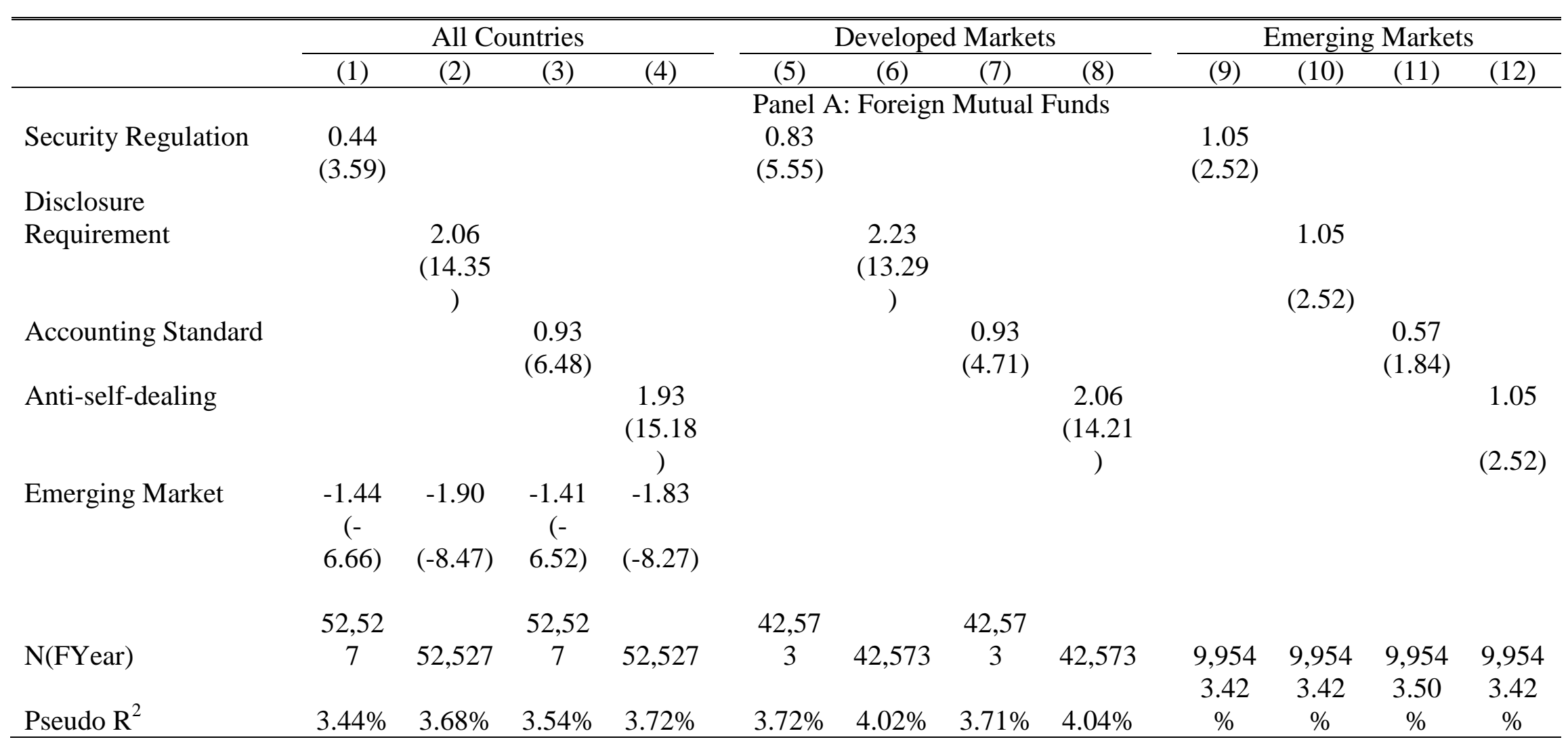


Table 6 (Continued)

\begin{tabular}{|c|c|c|c|c|c|c|c|c|c|c|c|c|}
\hline & \multicolumn{4}{|c|}{ All Countries } & \multicolumn{4}{|c|}{ Developed Markets } & \multicolumn{4}{|c|}{ Emerging Markets } \\
\hline & $(1)$ & $(2)$ & (3) & (4) & $(5)$ & $(6)$ & $(7)$ & $(8)$ & $(9)$ & $(10)$ & (11) & $(12)$ \\
\hline Security Regulation & $\begin{array}{c}-1.42 \\
(- \\
11.29)\end{array}$ & & & & $\begin{array}{c}\text { Panel B } \\
-1.29 \\
(- \\
9.19)\end{array}$ & Domest & c Mutua & Funds & $\begin{array}{r}4.25 \\
(9.58)\end{array}$ & & & \\
\hline Disclosure & & & & & & & & & & & & \\
\hline Requirement & & $\begin{array}{c}1.51 \\
(11.34\end{array}$ & & & & 0.73 & & & & 4.25 & & \\
\hline & & ) & & & & $(4.55)$ & & & & $(9.58)$ & & \\
\hline Accounting Standard & & & $\begin{array}{c}-0.06 \\
(- \\
0.50)\end{array}$ & & & & $\begin{array}{c}-1.56 \\
(- \\
9.64)\end{array}$ & & & & $\begin{array}{c}4.01 \\
(14.43 \\
)\end{array}$ & \\
\hline Anti-self-dealing & & & & 0.57 & & & & $\begin{array}{c}-0.08 \\
(-\end{array}$ & & & & 4.25 \\
\hline Emerging Market & $\begin{array}{l}-0.20 \\
(-0.87)\end{array}$ & $\begin{array}{l}-0.71 \\
(-3.19)\end{array}$ & $\begin{array}{c}-0.39 \\
(- \\
1.68)\end{array}$ & $\begin{array}{c}(4.74) \\
-0.47 \\
(- \\
2.06)\end{array}$ & & & & $0.60)$ & & & & $(9.58)$ \\
\hline & & & 50,63 & 50,63 & 40,09 & 40,09 & 40,09 & 40,09 & 10,53 & 10,53 & & 10,53 \\
\hline N(FYear) & 50,637 & 50,637 & 7 & 7 & 9 & 9 & 9 & 9 & 8 & 8 & 10,538 & 8 \\
\hline Pseudo $\mathrm{R}^{2}$ & $2.32 \%$ & $2.32 \%$ & $2.19 \%$ & $2.21 \%$ & $2.62 \%$ & $2.56 \%$ & $2.61 \%$ & $2.53 \%$ & $3.04 \%$ & $3.04 \%$ & $2.98 \%$ & $3.04 \%$ \\
\hline
\end{tabular}


make investment decisions. When countries are separated into developed and emerging markets, domestic investors demonstrate different weights on the country’s institutions. In developed countries, domestic investors care less about accounting standard and security regulations.

They also pay less attention to anti-self-dealing. It is worth noting that all institutions play a significant role on the domestic investors' decision making in the emerging markets. Although domestic investors possess more information of local firms, they still value the quality of laws and information disclosure at the country level. Therefore, good institutions not only attract more foreign capital, but also stimulate local people to invest in emerging market.

\subsection{Governance Role of Mutual Funds}

Ferreira and Matos (2008) document that mutual funds and independent investment advisors are likely to play a governance role because they have fewer connections with their holding companies and therefore the monitoring costs will be lower. From previous sections, foreign investors and domestic investors have different portfolio preferences in developed and emerging markets. Hence, it is interesting to see whether foreign and domestic investors can monitor firms effectively. In this subsection, we use return on assets (ROA) instead of firm value to test whether mutual funds play a monitoring role. As Ferreira and Matos document, firm value and foreign ownership may be endogenously determined because higher firm value may attract more foreign investors and foreign investors push up the price, which causes a high firm value. Using ROA as a proxy for firm performance is a better way to disentangle the monitoring effect of institutional investors.

Table 7 reports the results by regressing firms' ROA on foreign ownership or domestic ownership with control variables. Control variables include the entire firm characteristics used in Table 3. Year and country dummies are also added to control for year and country effects. From the results, it is obvious that both foreign and domestic mutual funds play a monitoring role on firms. Firm operating performance is positively associated with fund ownership. Particularly, domestic mutual funds seem to be a more effective monitor. For foreign mutual funds, funds' ownership is related to higher ROA in developed countries but the relation becomes insignificant in emerging countries. This indicates that foreign investors have difficulties to play an effective monitoring role for firms in emerging markets. However, the coefficients of domestic mutual 
Table 7: Operating performance and mutual fund ownership

This table reports the regression results of return on assets (ROA) on foreign and domestic mutual fund ownership in all markets, developed markets, and emerging markets. Control variables include variables used in Table 3. t-statistics reported in parentheses are calculated based on clustered firm-level heteroskedasticity-adjusted standard errors. N(FYear) is the number of firm-year observations. The sample period is from 1998 to 2007. Year and country dummies are added to control for year and country effects.

\begin{tabular}{|c|c|c|c|c|c|c|}
\hline \multirow[b]{2}{*}{ VARIABLES } & \multicolumn{3}{|c|}{ Foreign Mutual Funds } & \multicolumn{3}{|c|}{ Domestic Mutual Funds } \\
\hline & All & Developed & Emerging & All & Developed & Emerging \\
\hline \multirow[t]{2}{*}{ MF } & 0.03 & 0.03 & 0.01 & 0.05 & 0.05 & 0.09 \\
\hline & $(2.80)$ & (3.14) & $(0.46)$ & $(5.14)$ & (3.97) & $(4.68)$ \\
\hline \multirow[t]{2}{*}{ SIZE } & 0.32 & 0.29 & 0.22 & 0.33 & 0.31 & 0.30 \\
\hline & $(6.60)$ & (5.29) & (2.23) & $(6.82)$ & (5.66) & $(2.76)$ \\
\hline \multirow[t]{2}{*}{ BM } & -0.89 & -0.83 & -1.70 & -0.84 & -0.77 & -1.66 \\
\hline & $(-6.92)$ & $(-5.52)$ & $(-8.08)$ & $(-6.30)$ & $(-4.84)$ & $(-8.42)$ \\
\hline \multirow[t]{2}{*}{$\operatorname{Ret}_{12}$} & 18.62 & 20.71 & 12.70 & 17.12 & 18.67 & 10.99 \\
\hline & (10.06) & $(9.03)$ & (6.24) & (8.98) & (7.74) & (5.29) \\
\hline \multirow[t]{2}{*}{$\sigma_{\text {Ret }}$} & -16.65 & -21.68 & -1.49 & -16.62 & -20.59 & -3.87 \\
\hline & $(-9.49)$ & $(-10.44)$ & $(-0.86)$ & $(-8.98)$ & $(-8.58)$ & $(-1.87)$ \\
\hline \multirow[t]{2}{*}{ DY } & 26.83 & 25.70 & 31.55 & 25.54 & 25.06 & 31.06 \\
\hline & (10.29) & $(8.21)$ & (7.07) & $(9.70)$ & $(7.60)$ & (7.32) \\
\hline \multirow[t]{2}{*}{ ROE } & 28.71 & 29.44 & 22.08 & 31.12 & 32.00 & 23.12 \\
\hline & $(40.22)$ & (36.85) & (18.38) & (43.05) & (39.40) & (21.31) \\
\hline \multirow[t]{2}{*}{ MSCI } & -0.25 & -0.13 & -0.02 & -0.48 & -0.33 & -0.25 \\
\hline & $(-1.96)$ & $(-0.90)$ & $(-0.07)$ & $(-3.56)$ & $(-2.12)$ & $(-0.93)$ \\
\hline \multirow[t]{2}{*}{ DA } & -0.69 & -0.61 & -2.36 & -1.09 & -1.06 & -2.64 \\
\hline & $(-2.42)$ & $(-1.86)$ & $(-4.44)$ & $(-3.69)$ & $(-3.08)$ & $(-5.40)$ \\
\hline \multirow[t]{2}{*}{$\mathrm{CASH}$} & -3.25 & -4.29 & 6.21 & -3.77 & -5.01 & 6.36 \\
\hline & $(-4.68)$ & $(-5.57)$ & $(6.02)$ & $(-5.42)$ & $(-6.43)$ & (6.77) \\
\hline \multirow[t]{2}{*}{ CHold } & 1.36 & 1.85 & -0.02 & 1.12 & 1.60 & 0.24 \\
\hline & (5.03) & (5.93) & $(-0.04)$ & (3.76) & (4.54) & $(0.52)$ \\
\hline \multirow[t]{2}{*}{ gSales x100 } & 0.03 & 0.03 & -0.08 & 0.02 & 0.02 & -0.10 \\
\hline & (2.74) & (2.85) & $(-2.82)$ & (1.27) & (1.63) & $(-3.52)$ \\
\hline \multirow[t]{2}{*}{ ADR } & -0.80 & -0.76 & -0.45 & -0.35 & -0.22 & -0.42 \\
\hline & $(-2.66)$ & $(-2.29)$ & $(-0.73)$ & $(-1.19)$ & $(-0.67)$ & $(-0.69)$ \\
\hline \multirow[t]{2}{*}{ AGE } & -0.01 & -0.01 & -0.08 & 0.01 & 0.00 & -0.07 \\
\hline & $(-0.91)$ & $(-1.38)$ & $(-3.04)$ & (1.07) & $(0.37)$ & $(-2.96)$ \\
\hline N(FYear) & 52,792 & 42,844 & 9,948 & 50,821 & 40,292 & 10,529 \\
\hline Adjusted $\mathrm{R}^{2}$ & 0.51 & 0.51 & 0.51 & 0.54 & 0.53 & 0.53 \\
\hline
\end{tabular}


fund ownership are all significant in both developed and emerging markets. This monitoring effect of domestic mutual funds is especially strong in emerging markets.

Among all control variables, it is worth noting that size, past performance, dividend yields, and ROE are all positively associated with ROA. However, closely-held ownership has a positive effect on the ROA in developed countries, but the effect disappears in emerging markets. Results show that higher insider ownership does improve operating performance, but this relation only exists in developed countries. In the emerging markets, there is a lack of law enforcement to protect investors, resulting in higher monitoring costs for shareholders. Because the penalties from being caught by laws or sued by shareholders are relatively minor, firm managers in emerging markets with higher ownership may actually use their power to extract private benefits from shareholders and to deter shareholders from playing monitoring role. It is also widely documented that good corporate governance is enforced through lower cash holdings (see e.g., Yun, 2009). If this is the case, cash holdings should be negatively related to firm performance. As shown in Table 7, the coefficient of cash holdings is negative, except emerging markets. In the emerging markets, cash holdings have a positive effect on firm performance, implying that cash holdings may play a different role in developed and emerging markets.

\section{Conclusions}

This study investigates the portfolio preferences of foreign and domestic mutual funds in developed and emerging markets. The sample covers 28 countries, 28,602 foreign mutual funds, 23,373 domestic mutual funds, and 92,747 firm-years from 1998 to 2007. Previous studies in general only use the sample from developed or emerging markets with one year of data. They also focus on foreign investors to explore the preferences of asset allocation. It is still unclear whether previous findings apply to both domestic and foreign investors and remain evident in either developed or emerging markets. The maintained hypothesis is that firms in different markets have different structures. Since foreign investors have information disadvantage in local markets, foreign and domestic investors should have different preferences when they form their portfolio holdings. This study uses both domestic and foreign mutual funds in developed and emerging markets to first investigate the overall portfolio preferences and then their portfolio 
preferences in each market.

Results show that foreign and domestic investors have some different portfolio preferences, and these preferences vary between developed and emerging markets. Foreign mutual funds in the developed markets prefer firms with large size, lower dividend yields, higher ROE, more cash holdings, and fewer closely-held shares. They also like young growth stocks, firms listed in the MSCI index, and firms that have ADR issuance. In emerging markets, they focus more on firms' operating performance, such as ROE and sales growth, but less on ADR issuance. Contrary to foreign mutual funds, domestic mutual funds overall do not care about MSCI membership and ADR issuance. Firm size and dividend yields also play a small role in domestic mutual funds' portfolio holdings. Such findings are consistent in developed markets. In emerging markets, domestic mutual funds place a greater emphasis on dividend yields, ROE, and sales growth.

Firms' information environments also affect both foreign and domestic mutual funds' portfolio preferences. Three dimensions of measure - accounting standards, earnings management, and analyst variables - are utilized to proxy for the level of the firms' information asymmetry. Results indicate that accounting standards and analyst-related measures are significantly related to fund ownership for both foreign and domestic mutual funds. However, the positive effect of strong accounting standards and lower analyst forecast dispersion reduces for foreign mutual funds in emerging markets but remains significant for domestic mutual funds. Among all measures, the number of analysts covering a firm is the most important.

Results also would suggests that foreign mutual funds obviously invest less in emerging markets. Higher GDP, larger equity market size, and higher GDP growth exhibit negative effects and foreign trades have a positive effect on foreign mutual funds. For domestic mutual funds, ownership is positively related to stock market size and negatively related to foreign trades. To explore whether institutions affect fund managers' intentions to invest, four measures are used: security regulation, disclosure requirement, accounting standard, and anti-self-dealing. Results show that all measures for a country's institutions affect foreign mutual funds' intentions to invest in firms in the country. The findings are consistent for both developed and emerging markets. However, domestic mutual funds only care about disclosure requirements in developed markets while all four measures matter in emerging markets. Further results show that both 
foreign and domestic mutual funds are able to play a monitoring role for firms, but foreign mutual funds can only monitor firms effectively in developed markets.

Author Information: Wen-Hsiu Chou is from the Department of Finance and Real Estate, College of Business Administration, Florida International University, Miami, FL 33199. Author's contact information: wchou@fiu.edu, (305) 348-0533.

\section{References}

Aggarwal, R., I. Erel, M. Ferreira, and P. Matos, (2011). Does governance travel around the world? Evidence from institutional investors, Journal of Financial Economics, 100: 154-181.

Aggarwal, R., L. Klapper, and P.D. Wysocki, 2005, Portfolio preferences of foreign institutional investors, Journal of Banking \& Finance, 29: 2919-2949.

Bohn, H. and L.L. Tesar, (1996). U.S. portfolio investment in foreign markets: Portfolio rebalancing or return chasing? American Economic Review, 86: 77-81.

Bradshaw, M., B. Bushee, and G. Miller, (2004). Accounting choice, home bias, and U.S. investment in non-U.S. firms, Journal of Accounting Research, 42: 795-841.

Chan, K., V. Covrig, and L. Ng, (2005). What determines the domestic bias and foreign bias? Evidence from mutual fund equity allocations worldwide, Journal of Finance, 60: 14951534.

Covrig, V., M. DeFond, and M. Hung, (2007). Home bias, foreign mutual fund holdings, and the voluntary adoption of international accounting standards, Journal of Accounting Research, 45: 51-70.

Dahlquist, M. and G. Robertsson, (2001). Direct foreign ownership, institutional investors, and firm characteristics, Journal of Financial Economics, 59: 413-440.

Daske, H., L. Hail, C. Leuz, and R. Verdi, (2011). Adopting a label: heterogeneity in the economic consequences around voluntary IAS adoptions, Working Paper at University of Mannheim.

Fan, J., J. Wei, and X. Xu, (2011). Corporate finance and governance in emerging markets: A selective review and an agenda for future research, Journal of Corporate Finance, 17: 207214.

Ferreira, M.A. and P. Matos, (2008). The colors of investors' money: The role of institutional investors around the world, Journal of Financial Economics, 88: 499-533.

Francis, J.R., (2004). What do we know about audit quality? British Accounting Review, 36: 345368.

Francis, J.R. and D. Wang, (2008). The joint effect of investor protection and big 4 audits on earnings quality around the world, Contemporary Accounting Research, 25: 157-191.

Gelos, R.G. and S. Wei, (2005). Transparency and international portfolio holdings, Journal of Finance, 60: 2987-3020.

Kang, J.K. and R. Stulz, 1997, Why is there a home bias? An analysis of foreign portfolio equity ownership in Japan, Journal of Financial Economics, 46: 3-28.

La Porta, R., F. Lopez-de-Silanes, and A. Shleifer, 2006, What works in securities laws?, Journal of Finance, 61: 1-32. 
La Porta, R., F. Lopez-de-Silanes, A. Shleifer and R. W. Vishny, (1998). Law and finance, Journal of Political Economy, 106: 1113-1155.

Leuz, C., K.V. Lins, and F.E. Warnock, 2009, Do foreigners invest less in poorly governed firms? Review of Financial Studies, 22: 3245-3285.

Leuz, C., D. Nanda, and P.D. Wysocki, (2003). Earnings management and investor protection: An international comparison, Journal of Financial Economics, 69: 505-527.

Lai, S., L. Ng, and B. Zhang, (2012). Does PIN vary and affect asset prices around the world?, Working paper.

Yun, H., (2009). The choice of corporate liquidity and corporate governance, Review of Financial Studies. 